\title{
Effect of MDR C3435T polymorphism on Varenicline treatment in quit smoking
}

\author{
Nurgul Bozkurt", *, Fatih Altıntas², Ali Ihsan Bozkurt³, Gunfer Turgut ${ }^{2}$, Sebahat Turgut ${ }^{2}$ \\ ${ }^{1}$ Pamukkale University, Medical Faculty, Department of Pulmonary Medicine, Turkey, ${ }^{2}$ Pamukkale University, Medical \\ Faculty, Department of Physiology, Turkey, ${ }^{3}$ Pamukkale University, Medical Faculty, Department of Public Health, Turkey
}

\begin{abstract}
Despite so many global efforts, smoking still remains to be one of the most common addictions worldwide. Even though most smokers wish to quit smoking, many of them fail. In this respect, genetic variants are thought to be remarkable factors in nicotine dependence and in treatment of smoking cessation. This is a paper investigating a single variant p-glycoprotein (P-gp) polymorphisms and its effect on Varenicline efficacy in the smoking cessation. 158 smokers and 52 non-smoker healthy volunteers were included. We determined the P-gp C3435T gene polymorphisms in all subjects. Face to face interviews with smokers were performed for smoking cessation and Varenicline was given for smoking cessation. Cessation success was evaluated in the $6^{\text {th }}$ month and success rates were compared according to the P-gp genotype distributions. In our study, smoking cessation rate by Varenicline was $57.0 \%$. This rate was $55.0 \%$ in females, and $57.2 \%$ in males $(\mathrm{p}=0.85)$. The P-gp C3435T gene distribution was similar in control, quitters and not-quitter groups. Cessation rate was at highest point in genotype CT (62.2\%) and at the lowest in TT (47.6\%). It was $53.8 \%$ in genotype CC and there was no statistically significant difference $(\mathrm{p}=0.27)$. Our results suggest that genetic variants of P-gp C3435T did not significantly affect Varenicline treatment for smoking cessation.
\end{abstract}

Keywords: Polymorphism. Smoking Cessation/methods. Varenicline/analysis. Varenicline/adverse effects. Smoking/genetics. Genetic/drug effects.

\section{INTRODUCTION}

Smoking is common in all countries and a major cause of mortality and health problems in worldwide (Jha, Peto, 2014). According to the World Health Organization (2012), globally $12 \%$ of all deaths among adults aged 30 years and over were attributed to tobacco.

Several studies have reported that $60-70 \%$ of smokers wish to quit (Aveyard, West, 2007), but only $3-5 \%$ of them remain abstinent for a year after an unassisted attempt (Zhu et al., 2000).

In this respect, pharmacological treatment remains an important resource for smoking cessation. Generally, three pharmaceutical interventions are Nicotine Replacement Therapy, Varenicline and Bupropion (Mills et al., 2012). Varenicline is a partial agonist at the $\alpha 4 \beta 2$ nicotinic acetylcholine receptor (Rollema et al., 2010; Obach et al.,

\footnotetext{
*Correspondence: Nurgul Bozkurt. Department of Pulmonary Medicine Medical, Faculty of Pamukkale University, Gerzele mah., Geriz Cad Yağmurkent Sitesi B Blok D-6 Denizli - Turkey. Telephone: +90 5425270525. E-mail: drnbozdemir@gmail.com
}

2006). Previous studies have indicated that Varenicline is a more effective aid to smoke cessation than the others (Kotz, Brown, West, 2014; Walker et al., 2017). Despite its proven effectiveness, some patients do not still respond to Varenicline. At this point, individual differences in response to Varenicline can be caused by genetic factors (Santos et al., 2015; Tomaz et al., 2015).

Multi-drug resistant-1 (MDR-1) is a gene located on chromosome 7q21 and encodes a transporter protein called P-glycoprotein (P-gp), which is the member of a family of proteins in which only one subgroup has a role in multidrug resistance (MDR) (Miller, Bauer, Hartz, 2008). P-gp is responsible for the cellular efflux of a variety of drugs and cellular metabolites across the plasma membrane and reduces exposure to potentially toxic compounds of intracellular environment (Yamada et al., 2011). It is also suggested that this transporter functions as a protective barrier to keep toxins out of the body by excreting these compounds into bile (Wang et al., 2004), urine and intestinal lumen (Marzolini et al., 2004). In addition, $\mathrm{P}$-gp is released in the epithelium of brain 
choroid plexus, as well as the luminal surface of blood capillaries of brain (Cordon-Cardo et al., 1989).

The MDR1 gene is a highly polymorphic gene with more than 50 single-nucleotide polymorphisms (SNPs) (Breier et al., 2005). C3435T SNP is one of the most popular MDR1 polymorphisms and effects the expression and functions of P-gp (Hoffmeyer et al., 2000).

For that reason, we assume that $\mathrm{P}$-gp could be a factor that may affect the level of substance that can cause addiction once it penetrates into the brain.

Therefore, we aimed to determine the genotype and allele frequencies of MDR C3435T polymorphisms and to identify their relationship with Varenicline efficacy in smokers.

\section{MATERIAL AND METHODS}

\section{Subjects}

The study was performed between July 2015 and May 2016 at a smoking cessation clinic of Pamukkale University Medical Faculty, in Denizli, Turkey. When $\alpha=0.05$ and $\beta=0.2$ are accepted and the lowest person to be taken to work was found as 152 . Totally 158 cigarette smokers (male:138, female:20) were included in the study. Also 52 non-smoker healthy volunteers were included to the study as control group. Exclusion criteria for control and smoker groups are any chronicle disease.

A questionnaire included gender, age, Fagerström Test for Nicotine Dependence (FTND) (Heatherton et al., 1991), previous attempts to quit, former and current diseases and medications etc. was performed on smokers. In addition, face to face interviews with smokers were performed for smoking cessation. All smokers were prescribed Varenicline up to $0.5 \mathrm{mg}$ a daily for 3 days, then $0.5 \mathrm{mg}$ twice a day for 4 days, then $1.0 \mathrm{mg}$ twice a day for 11 weeks. The smoking cessation was planned to be 7-14 days after Varenicline initiation (Jorenby et al., 2006). After the first visit on the day $1^{\text {st }}$, follow-up visits were scheduled on days $15^{\text {th }}, 29^{\text {th }} 57^{\text {th }}$, and $85^{\text {th }}$. The self-reported smoking status and exhaled carbon monoxide concentrations were assessed on each visit. Then, smoking cessation success was evaluated in the $6^{\text {th }}$ month. Firstly, the genotype distributions of "smokers" and "non-smokers" were compared. Secondly, the genotype distributions of "quitters" and "non-quitters" were compared.

The study protocol conformed to the ethical guidelines of the Declaration of Helsinki as reflected in the previous approval released by the institution's human research committee. All volunteers were acknowledged about the study and written consent was taken. The study was approved by the Ethics Committee of Pamukkale University (PAU 02.09.2013/31488).

\section{Blood sample}

Blood samples from all subjects were collected into $2 \mathrm{ml}$ tubes containing ethylene diamine tetra acetic acid.

\section{Genetic analysis}

Deoxyribonucleic acid (DNA) samples were isolated from peripheral blood leukocytes by standard phenol/ chloroform extraction method (Ponez et al., 1982). MDR1 C3435T polymorphism of genotyped by polymerase chain reaction-restriction fragment length polymorphism (PCR-RFLP) method. PCR was performed with thermal cycler (Techgene, NJ, USA) and a PCR assay using the forward primer 5'-TGC TGG TCC TGA AGT TGA TCT GTG AAC-3' and the reverse primer 5' -ACA TTA GGC AGT GAC TCG ATG AAG GCA-3' 3' was performed with $10 \times$ buffer, $1.5 \mathrm{mM} \mathrm{MgCl}_{2}$ and $0.2 \mathrm{mM}$ each dNTP, $100 \mathrm{ng}$ genomic DNA and $1 \mathrm{U}$ Taq DNA polymerase (Ameyaw et al., 2001). The PCR protocol was as follows: initial 2 min at $94{ }^{\circ} \mathrm{C}$ followed by 35 cycles, consisting of denaturation for $30 \mathrm{~s}$ at $94{ }^{\circ} \mathrm{C}$, annealing for $30 \mathrm{~s}$ at $60^{\circ} \mathrm{C}$, and extension for $30 \mathrm{~s}$ at $72{ }^{\circ} \mathrm{C}$ (Schwab et al., 2003). The PCR product ( $248 \mathrm{bp}$ in size) was digested at $37{ }^{\circ} \mathrm{C}$ for 4 $\mathrm{h}$ with Mbol restriction enzyme (Fermentes, Germany), resulting in the following fragments: $172,60 \mathrm{bp}$ in wild type homozygotes (C/C genotype), 238 bp to T/T genotype and $238 \mathrm{pb}, 170 \mathrm{bp}$ and $60 \mathrm{bp}$ to the $\mathrm{C} / \mathrm{T}$ genotype. These fragments were separated with gel electrophoresis on $3 \%$ agarose gel stained with ethidium bromide, and observed under ultraviolet light.

\section{Statistical analysis}

SPSS 15.0 for Windows Computing Program was used for statistical analysis of the data. Statistical significance of the observed genotype frequencies was evaluated according to Hardy-Weinberg rule compared to the expected genotype frequencies. Hardy-Weinberg equilibrium was evaluated by the $\mathrm{x}^{2}$ test.

The difference in allele and genotype frequencies between the smokers and the ones in the control group was determined by using the chi-square test. The chisquare test was also used to compare difference between the smoking cessation rates according to genotype distribution. The ANOVA test was also used to compare the difference between FTND scores. 
Logistic regression analysis was used to determine the factors affecting smoking cessation.

\section{RESULTS}

There were 158 cigarette smokers and 52 never smokers (control group) in the current study. Cigarette smokers and control groups were compared. The mean age was similar in smokers and control group (respectively $36.7 \pm 9.5$ and $35.9 \pm 11.0),(p=0.6)$. Some characteristics of smokers were shown on Table I. The majority of smokers were male, married and high school graduates. The education and marital status were also similar in smokers and control group. Gender distribution between the groups was also evaluated. Percentage of men was significantly higher in smokers $(87.3 \%)$ than the control group $(32.7 \%)$, $(\mathrm{p}=0.01)$.

In current study, the MDR-1 C3435T gene distribution was investigated in terms of possible effects on smoking habit and smoking cessation. The frequency of the genotype MDR-1 C3435T gene in smokers and the control groups did not show a significant deviation from the Hardy-Weinberg equilibrium. Observed and expected frequencies for the gene were in Hardy-Weinberg equilibrium in both the smokers and the control groups, respectively, $(\chi 2=3.6 \mathrm{p}>0.05),(\chi 2=3.78, \mathrm{p}>0.05)$.

In the study population; MDR gene distribution based on gender was given on Table II. There was no statistically difference $(\mathrm{p}=0.08)$.

Varenicline treatment to quit smoking was given to all smokers. In our study, smoking cessation success was evaluated in the $6^{\text {th }}$ month and it was $57 \%$. This rate was evaluated based on gender, but no difference was found, $(\mathrm{p}=0.85)$, (Table III). It was $55.0 \%$ in females, and $57.2 \%$ in males.

The genotype distributions of the groups were compared on the Table IV. There was no significant difference between control and smoker groups in terms of genotype distribution ( $\mathrm{p}=0.56$ ). In addition, $\mathrm{C}$ and $\mathrm{T}$ allele presences were evaluated in these groups. Percentages of $\mathrm{C}$ and $\mathrm{T}$ allele presence were not significantly different (respectively $\mathrm{p}=0.29, \mathrm{p}=0.88$ ), (Table IV).

The MDR-1 C3435T genotype distributions of these two groups ("smoking quitters" and "non-quitters") were

TABLE I - Some socio-demographic features of the smokers and non-smokers

\begin{tabular}{|c|c|c|c|c|c|}
\hline & \multicolumn{2}{|c|}{ Smokers } & \multicolumn{2}{|c|}{ Non-smokers } & \multirow[t]{2}{*}{$\mathbf{p}^{*}$} \\
\hline & $\mathbf{n}$ & $\%$ & n & $\%$ & \\
\hline \multicolumn{6}{|l|}{ Gender } \\
\hline Male & 138 & 87.3 & 17 & 32.7 & \\
\hline Female & 20 & 12.7 & 35 & 67.3 & $\mathrm{P}=0.01$ \\
\hline \multicolumn{6}{|l|}{ Marital status } \\
\hline Not Married & 26 & 16.5 & 8 & 15.4 & \\
\hline Married & 132 & 83.5 & 44 & 84.6 & $\mathrm{P}=0.91$ \\
\hline \multicolumn{6}{|l|}{ Educational status } \\
\hline Primary school & 53 & 33.6 & 14 & 26.9 & \\
\hline High school & 73 & 46.2 & 26 & 50.0 & $\mathrm{P}=0.70$ \\
\hline University & 32 & 20.3 & 12 & 23.1 & \\
\hline Total & 158 & 100.0 & 52 & 100.0 & \\
\hline
\end{tabular}

*chi-square test results

TABLE II - The MDR-1 C3435T gene distribution according to gender in each person

\begin{tabular}{|c|c|c|c|c|c|c|c|c|}
\hline & & \multicolumn{4}{|c|}{ Gender } & \multirow{2}{*}{\multicolumn{2}{|c|}{ Total }} & \multirow{3}{*}{$\mathbf{p}^{*}$} \\
\hline & & \multicolumn{2}{|c|}{ Male } & \multicolumn{2}{|c|}{ Female } & & & \\
\hline & & $\mathbf{n}$ & $\%$ & $\mathrm{n}$ & $\%$ & $\mathrm{n}$ & $\%$ & \\
\hline \multirow{3}{*}{ Genotyppes } & $\mathrm{CC}$ & 31 & 20.0 & 4 & 7.3 & 35 & 16.7 & \multirow{3}{*}{0.08} \\
\hline & $\mathrm{CT}$ & 86 & 55.5 & 37 & 67.3 & 123 & 58.6 & \\
\hline & $\mathrm{TT}$ & 38 & 24.5 & 14 & 25.5 & 52 & 24.8 & \\
\hline Total & & 155 & 100.0 & 55 & 100.0 & 210 & 100.0 & \\
\hline
\end{tabular}

*chi-square test result 
TABLE III - The success of smoking cessation according to gender

\begin{tabular}{lccccc}
\hline & \multicolumn{2}{c}{ Smoking quitters } & \multicolumn{2}{c}{ Non-quitters } & \multirow{2}{*}{$\mathbf{p}^{*}$} \\
\cline { 2 - 5 } & $\mathrm{n}$ & $\%$ & $\mathrm{n}$ & $\%$ & \\
\hline Male & 79 & 57.2 & 59 & 42.8 & 0.85 \\
Female & 11 & 55.0 & 9 & 45.0 & \\
\hline Total & 90 & 57.0 & 68 & 43.0 & \\
\hline
\end{tabular}

*chi-square test result

TABLE IV - Comparisons of The MDR-1 C3435T genotypes and alleles distribution in all groups

\begin{tabular}{|c|c|c|c|c|c|c|c|c|c|c|c|}
\hline & \multicolumn{2}{|c|}{$\begin{array}{c}\text { Control } \\
(\mathrm{n}=52)\end{array}$} & \multicolumn{2}{|c|}{$\begin{array}{c}\text { Smokers } \\
(\mathrm{n}=158)\end{array}$} & \multirow[t]{2}{*}{$\mathbf{p}^{*}$} & \multicolumn{2}{|c|}{ Quitters (n=90) } & \multicolumn{2}{|c|}{$\begin{array}{c}\text { Non-quitters } \\
(\mathrm{n}=68)\end{array}$} & \multirow[t]{2}{*}{$\mathbf{p}^{*}$} & \multirow[t]{2}{*}{$\mathbf{p}^{* \#}$} \\
\hline & $\mathbf{n}$ & $\%$ & $\mathbf{n}$ & $\%$ & & $\mathbf{n}$ & $\%$ & $\mathbf{n}$ & $\%$ & & \\
\hline \multicolumn{12}{|l|}{ Genotypes } \\
\hline $\mathrm{CC}$ & 9 & 17.3 & 26 & 16.5 & & 14 & 15.6 & 12 & 17.6 & & \\
\hline $\mathrm{CT}$ & 33 & 63.5 & 90 & 57.0 & 0.56 & 56 & 62.2 & 34 & 50.0 & 0.27 & 0.43 \\
\hline $\mathrm{TT}$ & 10 & 19.2 & 42 & 26.6 & & 20 & 22.2 & 22 & 32.4 & & \\
\hline \multicolumn{12}{|l|}{ Alleles } \\
\hline C presence** & 42 & 80.8 & 116 & 73.4 & & 70 & 77.8 & 46 & 67.6 & 0.11 & 0.19 \\
\hline TT & 10 & 19.2 & 42 & 26.6 & 0.29 & 20 & 22.2 & 22 & 32.4 & & \\
\hline $\mathrm{T}$ presence $* * *$ & 43 & 82.7 & 132 & 83.5 & 0.88 & 76 & 84.4 & 56 & 82.4 & 0.73 & 0.93 \\
\hline $\mathrm{CC}$ & 9 & 17.3 & 26 & 16.5 & & 14 & 15.6 & 12 & 17.6 & & \\
\hline
\end{tabular}

*chi-square test results; ${ }^{* *} \mathrm{CC}+$ and $\mathrm{CT}+; * * * \mathrm{CT}+$ and $\mathrm{TT}+$; \# quitters, non-quitters and control groups were compared

compared and there was no significant difference in terms of genotype distribution ( $\mathrm{p}=0.27$ ), (Table IV). In addition, $\mathrm{C}$ and $\mathrm{T}$ allele presences were compared between these two groups, and no significant difference was observed $(\mathrm{p}=0.11),(\mathrm{p}=0.73),($ Table IV $)$.

A comparison on the genotype distributions of the three groups (quitters, non-quitters and control) were also done in Table IV. Genotype and alleles distributions of three groups were not different, $(\mathrm{p}=0.43)$, (Table IV). But one point is remarkable when three groups are compared: The $\mathrm{C}$ allele positivity was found $80.8 \%$ in the control group and $77.8 \%$ in quitters, while it decreases to $67.6 \%$ in non-quitters (Table IV). But this difference was not statistically significant $(\mathrm{p}=0.19)$. When viewed in reverse order; the TT genotype positivity was found as $19 \%$ in control group and $22 \%$ in smoking quitters' group, while it increased to $32 \%$ in non-quitters (Table IV).

Smoking cessation rate was $57.0 \%$ in the $6^{\text {th }}$ month. The quit rates according to genotype distribution were given in Figure I. In the presence of $\mathrm{C}$ allele, the quit rate was found $60.3 \%$, but it was $57.6 \%$ in the presence of $\mathrm{T}$ allele. The lowest quit-rate was observed in the TT genotype (47.6\%). But there was no statistically significant correlation between MDR 1 C3435T subgroups and smoking cessation rate.

The FTND score was used to determine the level of nicotine addiction. The correlation between FTND score and gene distribution, which may be related to the smoking cessation, was examined. FTND score was $5.65 \pm 2.48$ in those with CC genotype and $5.76 \pm 2.14$ in those with CT gene and $5.74 \pm 2.28$ in those with TT genotype. There was a mild increase in the presence of T allele This is not statistically significant $(\mathrm{p}=0.97)$.

Logistic regression analysis was done by modeling with possible variables (age, gender, education status, genotype status, FTND score) (Table V). The values in the two variables were determined at the limit of significance. These are FTND score and education status. According to multiple analysis results; Not being able to quit smoking was 3 times higher in high nicotine dependence persons than mild dependence $(p=0.06)$. Also it was 4.6 times more than high school graduates, compared to those who graduated from primary school $(p=0.06)$. According to genotype status, no difference was detected. The presence of $\mathrm{C}$ allele is slightly protective. In other words, in the person having the TT genotype, the probability of non-quitting increases 
TABLE V - Effective Factors on Smoking Cessation Success According to Regression Analysis

\begin{tabular}{|c|c|c|c|c|c|}
\hline & \multirow{2}{*}{ df } & \multirow{2}{*}{ Sig. } & \multirow{2}{*}{$\operatorname{Exp}(B)$} & \multicolumn{2}{|c|}{ 95\% C.I.for EXP(B) } \\
\hline & & & & Lower & Upper \\
\hline Gender (female) & 1 & .809 & .88 & .319 & 2.439 \\
\hline Age & 1 & .770 & .99 & .956 & 1.034 \\
\hline FTND score (mild) & 2 & .059 & & & \\
\hline middle & 1 & .364 & 1.44 & .657 & 3.149 \\
\hline high & 1 & .018 & 3.08 & 1.211 & 7.833 \\
\hline Education status (primary) & 3 & .061 & & & \\
\hline Secondary school & 1 & .187 & 1.99 & .717 & 5.509 \\
\hline High school & 1 & .008 & 4.64 & 1.506 & 14.314 \\
\hline University & 1 & .271 & 1.77 & .641 & 4.882 \\
\hline MDR (cc) & 2 & .227 & & & \\
\hline $\mathrm{CT}+$ & 1 & .381 & .66 & .262 & 1.670 \\
\hline $\mathrm{TT}+$ & 1 & .618 & 1.30 & .462 & 3.665 \\
\hline Constant & 1 & .388 & .42 & & \\
\hline
\end{tabular}

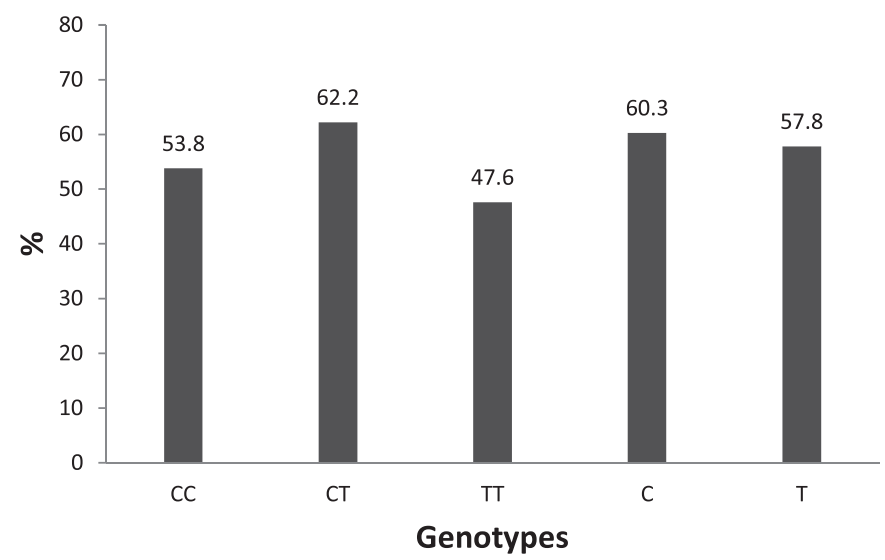

FIGURE 1 - Cessation rates by genotype distributions

1.3 times. However, this is not statistically significant $(\mathrm{p}=0.22)$.

\section{DISCUSSION}

Smoking remains the leading preventable cause of illness (Centers for Disease Control and Prevention, 2005). Research over the past three decades has identified effective treatments for smoking, including counseling, social support, and several pharmacotherapies (Fiore et al., 2008). However, current smoking cessation treatments have limited the efficacy (Thorndike et al., 1998; Solberg et al., 2001).

In our study; $87 \%$ of the smokers was male $(\mathrm{p}=0.001)$. According to the World Health Organization (2015), the smoking rate of men was five times higher than female; $36 \%$ vs. $7 \%$ respectively. Our findings are consistent with this report.

In current study, cessation rate was found as $57 \%$ in the $6^{\text {th }}$ month. This rate was $55.0 \%$ in female, and $57.2 \%$ in male. In various studies using Varenicline, success rates between $30 \%$ and $65 \%$ have been reported (Jorenby et al., 2006; Fagerström et al., 2010; Saglam, 2012).

Recent studies have indicated that some genes may affect Varenicline treatment during smoking cessation trials (Santos et al., 2015; King et al., 2012; Swan et al., 2012). King et al. (2012) provided the evidence referring that multiple genetic loci contributes to smoking cessation and therapeutic response. Santos et al. (2015) investigated CHRNA4 rs1044396 gene in smoking cessation study and reported that patients treated with Varenicline including TT or CT genotypes had an OR of 2.18 for smoking cessation success compared with patients with CC genotype. In addition to them, there are only two studies concerning the literature investigating the relationship between Varenicline and P-gp. According to Rollema (2010), Varenicline is neither a substrate nor an inhibitor of P-gp. Similar results were also reported in the other study (Faessel et al., 2008).

In current study, the MDR 1 C3435T gene distribution was investigated for possible effects on smoking cessation. Because P-gp is expressed as intestinal and blood-brain barrier and it reduces the exposure to potentially toxic compounds of intracellular environment (Yamada et al., 2011). We also assume that P-gp may be a factor that may affect the level of 
substance causing addiction once it penetrates into the brain.

On reviewing the literature; we did not find any studies on the MDR1 C3435T gene distribution and smoking. However, the genotype distribution of smokers was reported as similar to the genotype distribution of the normal population in Denizli (Turgut, Turgut, Atalay, 2006).

When we look at our findings; genotype and alleles distributions of three groups (smoking quitters, nonquitters and control groups) did not different $(\mathrm{p}=0.43)$.

Similar smoking cessation rates were also obtained in each genotype groups (47.6\% in TT genotype, $53.8 \%$ in CC genotype, $62.2 \%$ in CT genotype $),(p=0.27)$. In addition, similar FTND scores were obtained in each group $(\mathrm{p}=0.97)$.

When the factors affecting the cessation rates are analyzed by multivariate analysis; as expected, the rates of non-quitters were high in high nicotine addicts. Also the rates of non-quitters were high in high school graduates. In addition; MDR1 C3435T gene distribution didn't have an effect on smoking cessation.

These findings indicate that the MDR 1 C3435T gene distribution does not significantly affect the success of the Varenicline treatment. This data is compatible with the study carried by Rollema et al. (2010).

But nevertheless, there are some notable points in the current study even if it is not statistically significant.

1. The percentage of TT genotype in non-quitters $(32 \%)$ is slightly higher than quitters $(22 \%)$.

2. The FTND score indicating nicotine dependence was found to be slightly higher in the TT genotype carriers. And there was a positive correlation between the FTND score and the $\mathrm{T}$ allele carrier.

These findings have shown that individuals with TT genotypes may be more addicted to nicotine. Individuals with TT genotypes have lower levels of P-gp, and these individuals may be exposed to more toxic substances (Schwab et al., 2003). Because P-gp is expressed intestinal and blood-brain barrier and reduces exposure to potentially toxic compounds of intracellular environment (Yamada et al., 2011). We think that some of the substances in the P-gp deficiency may go into the brain and create addiction. Consequently "non-quitters rate" increased 1.3 times in the presence of TT genotype.

The frequency of P-gp polymorphism in smokers has not been yet studied. In this context, our results are first and suggest that the smoking cessation success in Varenicline treatment is generally not affected by $\mathrm{P}-\mathrm{gp}$ polymorphism. However, the TT genotype may be a small risk factor for nicotine dependence.
There are some limitations in our study. First, our sample size of patients treated with Varenicline is relatively small and, consequently, our statistical power is relatively low. However, we were able to identify differences among genotypes, even including some potential confounders. But we were not able to add other biological aspects or environmental factors which could be important, such as functionality of the receptors, depression and motivation.

\section{CONCLUSIONS}

The smoking cessation success in Varenicline treatment is generally not affected by the MDR $1 \mathrm{C} 3435 \mathrm{~T}$ gene polymorphism. However, the TT genotype seems related to be nicotine dependence.

\section{ACKNOWLEDGMENTS}

"No assistance in the preparation of this article is to be declared".

There is no any sponsorship/funding.

There are no any financial, employment, other significant/relevant relationships.

This study was presented as a poster in FEBS 2017 Congress and abstract of study published in Acta Physiologica page 89.

\section{REFERENCES}

Ameyaw MM, Regateiro F, Li T, Liu X, Tariq M, Mobarek A, et al. MDR1 pharmacogenetics: frequency of the C3435T mutation in exon 26 is significantly influenced by ethnicity. Pharmacogenetics. 2001;11(3):217-21.

Aveyard P, West R. Managing smoking cessation. BMJ. 2007;335(7609):37-41.

Breier A, Barancík M, Sulová Z, Uhrik B. P-glycoproteinimplications of metabolism of neoplastic cells and cancer therapy Curr Cancer Drug Targets. 2005;5(6):457-68.

Centers for Disease Control and Prevention, CDC. Annual smoking-attributable mortality, years of potential life lost, and productivity losses-United States, 1997-2001. MMWR Morb Mortal Wkly Rep. 2005;54(25):625-8.

Cordon-Cardo C, O’Brien JP, Casals D, Rittman GL, Biedler JL, Melamed MR, et al. Multidrug resistance gene (P-glycoprotein) is expressed by endothelial cells at blood-brain barrier sites. Proc Natl Acad Sci USA. 1989;86(2):695-8. 
Faessel HM, Burstein AH, Troutman MD, Willavize SA, Rohrbacher KD, Clark DJ. Lack of a pharmacokinetic interaction between a new smoking cessation therapy, varenicline, and digoxin in adult smokers. Eur J Clin Pharmacol. 2008;64(11):1101-9.

Fagerström K, Nakamura M, Cho HJ, Tsai ST, Wang C, Davies S. Varenicline treatment for smoking cessation in Asian populations: a pooled analysis of placebo-controlled trials conducted in six Asian countries. Curr Med Res Opin. 2010;26(9):2165-73.

Fiore MC, Jaén CR, Baker TB, Bailey WC, Benowitz NL, Curry SJ, et al. Treating Tobacco Use and Dependence: 2008 Update. Clinical Practice Guideline. Rockville, MD: U.S. Department of Health and Human Services. Public Health Service. May 2008.United States.

Heatherton TF, Kozlowski LT, Frecker RC, Fagerström KO. The Fagerström Test for nicotine dependence: a revision of the Fagerström Tolerance Questionnaire. Br J Addict. 1991;86(9):1119-27.

Hoffmeyer S, Burk O, von Richter O, Arnold HP, Brockmöller J, Johne A, et al. Functional polymorphisms of the human multidrug-resistance gene: multiple sequence variations and correlation of one allele with P-glycoprotein expression and activity in vivo. Proc Natl Acad Sci USA. 2000;97(7):3473-8.

Jha P, Peto R. Global effects of smoking, of quitting, and of taxing tobacco. N Engl J Med. 2014;370(1):60-8.

Jorenby DE, Hays JT, Rigotti NA, Azoulay S, Watsky EJ, Williams KE, et al. Efficacy of Varenicline, an Nicotinic Acetylcholine Receptor Partial Agonist, vs Placebo or Sustained-Release Bupropion for Smoking Cessation. JAMA. 2006;296(1):56-63

King DP, Paciga S, Pickering E, Benowitz NL, Bierut LJ, Conti DV, et al. Smoking cessation pharmacogenetics: analysis of Varenicline and Bupropion in placebo-controlled clinical trials. Neuropsychopharmacology. 2012;37:641-50.

Kotz D, Brown J, West R. Effectiveness of Varenicline versus nicotine replacement therapy for smoking cessation with minimal professional support: evidence from an English population study. Psychopharmacology. 2014;231(1):37-42.

Marzolini C, Paus E, Buclin T, Kim RB. Polymorphisms in human MDR1 (P-glycoprotein): recent advances and clinical relevance. Clin Pharmacol Ther. 2004;75(1):13-33.
Miller DS, Bauer B, Hartz AM. Modulation of P-glycoprotein at the blood-brain barrier: opportunities to improve central nervous system pharmacotherapy. Pharmacol Rev. 2008; 60(2):196-209.

Mills EJ, Wu P, Lockhart I, Thorlund K, Puhan M, Ebbert JO. Comparisons of high-dose and combination nicotine replacement therapy, Varenicline, and bupropion for smoking cessation: a systematic review and multiple treatment metaanalysis. Ann Med. 2012;44(6):588-97.

Obach RS, Reed-Hagen AE, Krueger SS, Obach BJ, O’Connell TN, Zandi KS et al. Metabolism and disposition of Varenicline, a selective $\alpha 4 \beta 2$ acetylcholine receptor partial agonist, in vivo and in vitro. Drug Metab Dispos. 2006;34(1):121-30.

Ponez M, Solowiejczyk D, Harpel B, Mory Y, Schwartz E, Surrey S. Construction of human gene libraries from small amounts of peripheral blood. Hemoglobin. 1982;6(1):27-36.

Rollema H, Shrikhande A, Ward KM, Tingley FD, Coe JW, O'Neill BT et al. Pre-clinical properties of the alpha4beta2 nicotinic acetylcholine receptor partial agonists Varenicline, cytisine and dianicline translate to clinical efficacy for nicotine dependence. Br J Pharmacol. 2010;160(2):334-45.

Saglam L. Investigation of the results of a smoking cessation clinic and the factors associated with success. Turk J Med Sci. 2012;42(3):515-22.

Santos JR, Tomaz PR, Issa JS, Abe TO, Krieger JE, Pereira AC et al. CHRNA4 rs1044396 is associated with smoking cessation in Varenicline therapy. Front Genet. 2015;6:46-54.

Schwab M, Scbhaeffeler E, Marx C, Fromm MF, Kaskas B, Metzler J, et al. Association between the C3435T MDR1 gene polymorphism and susceptibility for ulcerative colitis. Gastroenterology. 2003;124(1):26-33.

Solberg LI, Boyle RG, Davidson G, Magnan SJ, Carlson CL. Patient satisfaction and discussion of smoking cessation during clinical visits. Mayo Clin Proc. 2001;76:138-43.

Swan GE, Javitz HS, Jack LM, Wessel J, Michel M,. Hinds DA, et al. Varenicline for smoking cessation: nausea severity and variation in nicotinic receptor genes. Pharmacogenomics J. 2012;12(4):349-58.

Thorndike AN, Rigotti NA, Stafford RS, Singer DE. National patterns in the treatment of smokers by physicians. JAMA. 1998;279(8):604-8. 
Tomaz PR, Santos JR, Issa JS, Abe TO, Gaya PV, Krieger JE. CYP2B6 rs2279343 polymorphism is associated with smoking cessation success in bupropion therapy. Eur J Clin Pharmacol. 2015;71(9):1067-73.

Turgut S, Turgut G, Atalay EÖ. Genotype and allele frequency of human multidrug resistance (MDR1) gene C3435 T polymorphism in Denizli province of Turkey. Mol Biol Rep. 2006;33:295-300.

Walker NJ, van Woerden HC, Kiparoglou V, Yang Y, Robinson H, Croghan E. Gender difference and effect of pharmacotherapy: findings from a smoking cessation service. BMC Public Health. 2017; 17:294-302.

Wang BL, Zhai HY, Chen BY, Zhai SP, Yang HY, Chen ZP et al. Clinical relationship between MDR1 gene and gallbladder cancer. Hepatobiliary Pancreat Dis Int. 2004;3:296-9.
World Health Organization. WHO Global Report: Mortality Attributable to Tobacco. Geneva: World Health Organization; 2012.

World Health Organization. WHO global report on trends in prevalence of tobacco smoking 2015. Geneva: WHO; 2015. [access in 2018 Jan. 20]. Avaliable from: http://www.who.int/ iris/bitstream/10665/156262/1/9789241564922_eng.pd.

Yamada O, Ozaki K, Furukawa T, Machida M, Wang YH, Motoji $\mathrm{T}$, et al. Activation of STAT5 confers imatinib resistance on leukemic cells through the transcription of TERT and MDR1. Cell Signal. 2011;23(7):1119-27.

Zhu S, Melcer T, Sun J, Rosbrook B, Pierce JP. Smoking cessation with and without assistance: a population-based analysis. Am J Prev Med. 2000; 18:305-11.

Received for publication on $10^{\text {th }}$ March 2018 Accepted for publication on $12^{\text {th }}$ June 2018 